\title{
Vaginal Non-Keratinizing Squamous Cell
} Carcinoma

National Cancer Institute

\section{Source}

National Cancer Institute. Vaginal Non-Keratinizing Squamous Cell Carcinoma. NCI

Thesaurus. Code C40244.

A squamous cell carcinoma that arises from the vagina and is characterized by the presence of polygonal squamous cells. Intercellular bridges and cytoplasmic keratinization may be present, but keratin pearls are absent. 